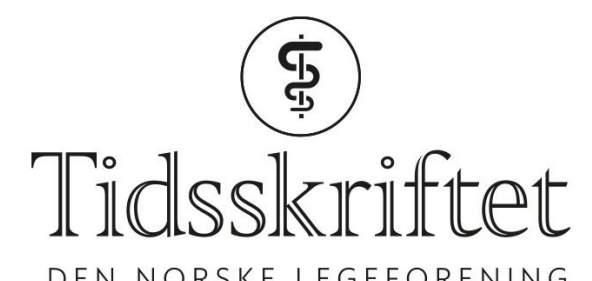

DEN NORSKE LEGEFORENING

\title{
Nyttig om intervensjonsstudier
}

ANMELDELSER

KJETIL SøREIDE

Redaktør, British Journal of Surgery

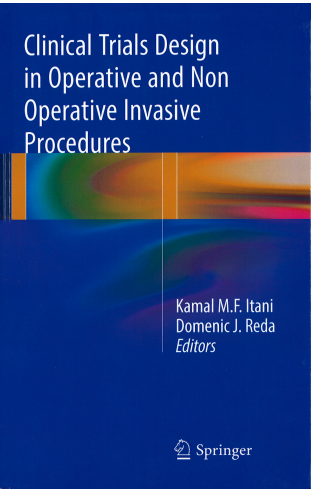

Kamal M.F. Itani, Domenic J. Reda, red.

Clinical trial design in operative and non operative invasive procedures

495 s, tab, ill. Cham: Springer, 2017. Pris EUR 170

ISBN 978-3-319-53876-1

Denne boken er særdeles nyttig og unik av flere grunner, men mest fremtredende er fokus på studiedesign ved intervensjoner (i motsetning til medikamentstudier) og innhold rettet mot kirurger og andre som driver en intervensjonsbasert praksis. Bokens idé har sitt utspring fra en forelesnings- og kursserie som er holdt i den amerikanske kirurgiforeningen. De fleste forfatterne er således kirurger, men også eksperter innen studiedesign og biostatistikk er med. Bokens forord er blant annet forfattet av Edvard Livingston, kirurg og nåværende redaktør i JAMA, som lovpriser bokens betydning for planlegging og gjennomføring av studier med et intervensjonsformål.

Boken er bygd opp av 11 deler bestående av totalt 54 kapitler. Den starter med basic principles - det helt grunnleggende studiespørsmålet og formulering av hypotese diskuteres sammen med valg av endepunkter (primære og sekundære), kontrollgrupper og valg av studiedeltakere. Del to tar for seg ulike studiedesign i egne kapitler, på en informerende måte. Statistiske elementer er nyttig og instruktivt omtalt i del tre, mens etiske betraktninger er godt diskutert i etterfølgende del. Deretter kommer en del matnyttige innspill for kirurger, der betraktninger spesifikt angående prosedyrebasert design trekkes frem. Særegne problemstillinger til intervenssjonsstudier belyses (som kvalitetssikring av prosedyrer; læringskurve; pasientutvalg; bruk av placebo-kirurgi eller «sham-procedures»; vurdering av «equipoise»). Regulative forhold som diskuteres i del seks er dels spesifikke for 
Nord-Amerika, men har likevel en del generelle tips av verdi. Et nyttig kapittel (som er del syv) dekker vanlige feil og typiske fallgruver for alle som planlegger studier. Del åtte beskriver en del varianter i studiedesign, som kombinerte studier og tilvalg som kombinerte medikament- og intervensjonsstudier; inkludering av genomikk og biomarkører; og bruk av økonomiske analyser. Budsjett hører med (del ni), samt finansiering (del ti), og sist, men viktigst, nemlig publisering av resultater. Således er man didaktisk ført gjennom nær sagt det meste i design og metodevurdering hva gjelder prosedyrebaserte studier, og flere av kapitlene har et nært kirurgisk innhold og budskap. Boken egner seg neppe som perm-til-perm lektyre for de fleste, til det er stoffet for fagtungt. Som oppslagsverk og til kapittel-for-kapittel bruk opplever jeg den imidlertid som veldig nyttig. De fleste kapitlene har rikelig med tilleggsreferanser, og innholdet er summert i enkle figurer og tabeller. Denne boken vil nok bli besøkt ved flere anledninger, spesielt som referanse i mitt virke som redaktør i et kirurgisk tidsskrift. Den anbefales til alle som planlegger eller har interesser for prosedyrebaserte studier.

Publisert: 15. oktober 2018. Tidsskr Nor Legeforen. DOI: 10.4045/tidsskr.18.0498

(C) Tidsskrift for Den norske legeforening 2020. Lastet ned fra tidsskriftet.no 